\title{
The Innovative Teaching Mode Exploration of Environmental Engineering Undergraduates in Network Information Age
}

\author{
J. L. JIA, L. N. ZHAO \& Y. YU \\ School of Chemical and Environmental Engineering, China University of Mining \& Technology (Beijing), \\ Beijing, 100083, China.
}

\begin{abstract}
According to the teaching characteristics of environmental engineering in network and information age, one practical innovative teaching mode of professional courses was discussed in this paper. In undergraduate students' teaching process, the positive role of network and information should be used as platform to improve the students' interest and ability. And on the other hand, teachers should make full use of the network environment support to explore the combined interactive teaching mode of environmental engineering in the new teaching area. As a result, the application of the knowledge learned from the professional course can be strengthened and finally the comprehensive ability can be improved. The opinion and teaching mode supplied in this paper can provide high-quality personnel and reserve force for the development of the environment engineering field such as environmental remediation and management area.

KEYWORD: Teaching Mode Innovation; Environmental Engineering; Network and Information Age
\end{abstract}

\section{INTRODUCTION}

University education as an important comprehensive part of our education are widely concerned in Chinese education system because of its three major functions teaching, scientific research and social service. In recent years, with the explosion of network information university teaching is also affected at the same time as the public life is affected Students are exposed to diverse sources of knowledge due to information transparency and openness, then teachers' authoritative status is declined and the undergraduate teaching activities are full of new characteristics.

The impacts of network and information age to university teaching based on the characteristics of professional course teaching process of environment engineering were discussed in detail in this paper. And the integrated interactive teaching mode for environment engineering undergraduates through the way of flexibility, innovation and interest cultivation were discussed as a beneficial exploration.

\section{THE TEACHING MODE OF UNIVERSITY IN NETWORK ERA AND ITS CHARACTERISTICS}

\subsection{Classification of the teaching model of University and its characteristics}

The university teaching mode can be classified as three kinds according to the role in the teaching activities of teachers and students, and according to students' state of active learning:

(1) Teaching mode under which teachers and students systematically teach and learn the book knowledge, under this mode, teachers play the primary role by teaching students through the topdown way to impart knowledge, and the teaching and re-search level in the professional field of the teachers has great impact on the teaching effect and even plays a decisive role this mode may combine knowledge points systematically, but lead to initiative of students to be deficient, and also easy to make the teaching activities boring.

(2) The second mode is where teachers' guide students to learn themselves from activities, this mode takes students as primary body, make full use of students' initiative to learn. This mode requests students to have certain professional knowledge background and have a strong desire to learn. At the same time, teachers need fully integrate knowledge into de-signed activities to guide the overall direction of students' activities and learning. 
This teaching mode guiding students learn from activities, is commonly used in experiment course, innovative cultivate links and practical links, or can applied in part of cases or links or can be applied in part of cases or links during curriculum teaching.

(3) The compromise between the two teaching modes, also known as the compound teaching mode, is about unifying teachers' teaching and students' learning organically to constitute the overall common composition of teaching.

This pattern is a generally seen teaching mode in present university course, it re-quires teachers combine imparting knowledge and flexible application organically to achieve the desired teaching objectives.

\subsection{The new characteristics of university professional course teaching in network information age}

There is a large amount of information in the network information age, and the in-formation is updated quickly, especially now the network is available in public teaching and research places such as classroom, dormitory, library, laboratories, offices and other places. The network makes information available very convenient, and it has great influence on university course teaching. This influence can be positive, but also can have certain interference on traditional teaching.

(1)The authority of teachers declines

The network includes a wide range of forums and websites. The definition, con-tents, ideas and methods to solve scientific problems of various concepts and scientific problems, is various, and may be some different with traditional textbooks. However, the student's professional level and discriminate ability is limited. When they can't make a reasonable judgment, they usually doubt the authority of teachers in the professional or course teaching. Then students will doubt the teachers' role and function in teaching activities, and the teaching effect will be affected.

(2)The existence of impact on the nor-mal teaching activities

For college students, examples that teaching is affected due to network indulged have often occurred. This phenomenon has attracted the attention of relevant education management department and related personnel in colleges and universities.

In addition, a variety of incentives of the network information age is also easy to make some students have a certain emotional weariness to environmental engineering. Then students may favors finance, management or literature. This trend will lead to a certain negative influence to learning interest ,attention and the final effect of students' whose major subjects are depended on the closely combination of mathematical model, calculation, experiment and practical ability.

(3)To provide more abundant means for the teaching of professional courses

To sum up, network information era against environmental engineering teaching mix impact with better platform provided. The key is teachers must fully capitalize on network information, amplify its ad-vantage, strengthen their own professional knowledge ability orientated guide and de-sign to avoid its negative impact on teaching activities, so as to achieve good teaching effect.

\section{THE NEW ENVIRONMENTAL ENGINEERING UNDERGRADUATE TEACHING MODE AND APPLICATION IN NETWORK INFORMATION ERA}

\subsection{Interactive teaching mode under the support of network information re-sources. The network provides a more rich alternative means and platforms for teaching. It can be fully utilized in the professional course teaching environmental engineerin}

Relying on the network platform, teachers can construct database of professional course teaching resource according to professional course division system. They should clear up the curriculum teaching and overall professional course teaching system to provide students with convenient, fast online learning platform.

To make use of network information re-sources to improve students' learning interest, strengthen teaching effect during the interactive teaching atmosphere. When the network information resource id used, the interaction between teachers and students is friendlier. It can help the improvement of the sense of rejection which brought by teachers age and position difference in students' mind. There is good reaction effect in the practical teaching activities. case with students more affinity, have brought to improve the teachers' age, differences in the student mind in the sense of rejection, good reaction effect in practical teaching;

Network resources and the traditional teaching way should be integrated organically and designed as a whole. Teachers should strengthen their guidance to urge students to sift the true from the false identify and utilize the related knowledge environment remediation case about environment engineering from net-work information resources, combined with the fast updating, strong timeliness characteristic of network resources, interpretating the new environmental events from the professional perspective to analyses on class or discuss afterschool, so as to make full use of network information resources in the professional course teaching. 


\subsection{Composite professional courses teaching and its application in environmental engineering based on the comparison of Chinese and foreign research}

For some research fields such as environmental pollution and control in environmental engineering. western developed countries' stage of development is earlier than China's, the research level is also higher, so, making full use of network in-formation resources to dynamically com-pare the discipline system and the development trend is meaningful to the implement and development of innovative composite teaching. It 'also the important form and component in the process of implementing the university composite teaching mode. Combined with the fact that the author has long been engaged in remediation of contaminated sites, environmental management teaching research and teaching "Environmental Soil Science" to analyze to situation now.

The example combines the author has long been engaged in remediation of contaminated sites and environmental management of teaching research and teaching "to analyze the environmental soil science".

Remediation of contaminated sites and environmental management is an important part of Environmental Soil Science. Developed countries such as the US and Europe system relatively complete systems and the system level is higher in this field. In China we develop late, don't have perfect laws, rules and management systems, Now we are in adjust period of development.

Base on the above basic characteristics. Using the Superfund management system on US Environmental Protection Agency (USEPA) websites to do dynamic comparison and demonstrations among human health risk, related regulations in china ,standard system and Remediation technology of environmental soil pollution, guide students with developing trend for professional field abroad dynamically, combined with domestic field application and management system to analyze the new developing direction of domestic environmental soil pollution management, in practical teaching application ,the reaction from students is very obvious.

In particular, soil contamination, and its restoration and management is a newer research direction than in the water environment and atmospheric environment in the field of environmental engineering. The teaching work of soil environment and its governance in the university is carried out late. Struggling to find Soil pollution relevant technical and management personnel is the present situation. Combined the research of dynamic trend analysis with modern teaching methods and network re-sources to strengthen students' creative and practical ability. It has a positive meaning not only in training reserve personnel in this field but also improve students' employment rate.

In summary, teachers should take advantage of the network of the network information age, avoid or reduce the impact and drawbacks to engineering courses teaching, strengthen and guide the professional knowledge of Environmental Engineering undergraduates, focus on training the students ability of field applications and solve scientific problems, To provide high-quality personnel and reserve forces for development of China's environmental remediation and related management.

\section{CONCLUSION}

In the network and information age, information comes convenient, fast and multi-channel sources not only impact Environmental Engineering Courses Teaching, but also provides a flexible teaching approach and platform. Making full use of it could help the students avoid weaknesses, improve interest and ability.

Composite interactive teaching mode which supported by network environment is becoming an effective way to new areas of environmental engineering teaching. This could improve the ability and interest of the flexibility to apply book learnings by vivid presentations and comparing re-search progresses and gaps home and abroad. So as to improve the utilization and comprehensive ability of students that studied in professional course.

\section{ACKNOWLEDGEMENT}

This paper is funded by the China University of Mining and Technology (Beijing) Course Construction Project (k140309).

\section{REFERENCES}

[1] Qin H., Jiang P. K., and Xu Q. F., et al. 2007. Teaching reform and practice of environmental soil science course for environmental science major, Higher Education Forum, No.4, pp.40-42

[2] USEPA. Superfund Risk Assessment: http://www.epa.govoswer/riskassessment/risk_superfund.htm.

[3] Li X. 2010. Research on bilingual teaching practice norm of higher education, China Adult Education, No. 5, pp. 114-115.

[4] Hu K., Xie Y. H., Hu J. P., et al. 2005. Discussion on the teaching contents and methods of environmental soil science, China Agricultural Education, No.6, pp.34-35.

[5] Liu T. F., Ding K. Q., Li H. Y., et al. 2012. The application of interactive teaching mode in environmental soil science teaching, China Pow.r Education, No.20, pp.72-73.

[6] Li S., Zhao D. F., Zhao C. C., et al. 2010. Research on teaching reform of environmental engineering based on practice. Science and Technology Innovation Herald, No. 21, 200. 